\title{
The Impact of Governing Institutions on Foreign Direct Investment Flows: Evidence from African Nations
}

\author{
David A. Wernick ${ }^{1}$, Jerry Haar $^{1} \&$ Latika Sharma ${ }^{2}$ \\ ${ }^{1}$ Department of Management and International Business, College of Business Administration, Florida International \\ University, Miami, USA \\ ${ }^{2}$ Information Technology Practice Area, The Boston Consulting Group, Gurgaon, India \\ Correspondence: Jerry Haar, Department of Management and International Business, College of Business \\ Administration, Florida International University, 11200 SW 8 Street, RB 352, Miami, FL 33199, USA. E-mail: \\ haarj@fiu.edu
}

Received: January 11, 2014

Accepted: February 23, 2014

Online Published: March 1, 2014

doi:10.5430/ijba.v5n2p1

URL: http://dx.doi.org/10.5430/ijba.v5n2p1

\begin{abstract}
Over the last two decades, industrialized nations and multilateral financial institutions have encouraged less developed countries to undertake institutional reforms to hasten socioeconomic development. Implicit in this advice is the idea that reform-minded countries will receive a foreign direct investment (FDI) dividend. But do nations with strong institutions attract proportionally greater levels of foreign direct investment (FDI) than those with weaker institutions? This study addresses that question by evaluating data on FDI inflows for a sample of African nations. We begin with a review of the literature on the determinants of FDI and the link between institutions and FDI flows to emerging economies. Next, we offer hypotheses about the nature of these flows and test them using statistical analysis. The paper concludes by interpreting the results, considering their policy implications, and offering directions for future research.
\end{abstract}

Keywords: governing institutions, Africa, Foreign Direct Investment (FDI)

\section{Introduction}

Researchers in academe, government, and multilateral organizations have expressed a growing interest in the relationship between institutions and national economic performance. Douglass North (1981; 1990), among others, have argued convincingly that the quality of governing institutions such as regulatory frameworks, administrative bodies, and judicial systems are prime determinants of long term economic prosperity. While North and other economists and industrial sociologists have focused on the macro dimension of the nexus between institutions and economic growth and development, other scholars and analysts have examined the micro dimensions of this phenomenon. For example, de Soto $(1989 ; 2000)$ contents that complex and cumbersome legal and regulatory hurdles to property ownership impede entrepreneurship, retard economic growth, and fuel a cycle of poverty in the developing world.

Based on a long-standing research program inspired by the work of North, de Soto, and others, the World Bank launched its World Governance Indicators (WGI) project in 1996. The project aggregates and reports governance indicators for 215 economies. based on six core dimensions of governance: voice and accountability, political stability and absence of violence, government effectiveness, regulatory quality, rule of law and control of corruption.The data captures the views of think-tanks, NGOs, international organizations and a large number of enterprise, citizen and expert survey respondents. The WGI project has driven extensive research into the relationship between the level of institutional development and economic performance.

While the impact of governance on overall economic development has been studied by academicians and policymakers, recent empirical work has focused rather narrowly on how institutions affect GDP growth rates and per capita income (e.g., Acemoglu and Johnson, 2005; Rodrik, Subramanian, and Trebbi, 2002). Relatively less has been written about the relationship between governing institutions and foreign direct investment (FDI) flows. FDI is widely regarded as a key source of foreign capital for developing countries, bringing with it jobs, access to technology, managerial know-how, new export markets, and other valuable assets (Wernick, Haar, and Singh, 2009). 
This paper seeks to determine the relationship between governance scores of a sample of 53 African nations and FDI inflows over a recent 11-year period (1996-2006). Rather than examining a single or several of the WGI governance variables, a composite scale has been developed to provide a snapshot of a country's overall institutional capacity using information captured by all six variables. Multiple regression models are used to test hypotheses about the relationship between the new scale and FDI performance.

This paper is organized as follows: The next section reviews the literature on the determinants of FDI and recent cross-disciplinary studies probing the connection between governing institutions and FDI flows to developing countries and offers hypotheses based on this literature. Section 3 provides an overview of FDI in Africa. Section 4 describes the data, variables, and methodology used in this study. Section 5 reports the results. Section 6 considers their policy implications and offers directions for future research.

\section{Literature Review and Expectations}

Extensive research has been carried out on the determinants of FDI flows to developing countries. The variables typically considered as vital for FDI include the size of the domestic market, natural resource endowments, physical infrastructure (e.g., roads, airports, seaports, the power grid), the degree of protection of the domestic market, geographical location of the host country, the degree of an economy's openness and the provision of fiscal incentives by the recipient country (Al-Sadig, 2013; De Vita and Kyaw, 2008; Grubaugh, 2013; Hussain and Kimuli, 2012; Sichei and Kinyondo, 2012; Soumia and Abderrezzak, 2013).

Macroeconomic factors including the growth rate of GDP, inflation, interest rates, international reserves, and external debt have also been identified as essential for FDI flows (Abbott, Cushman, and De Vita, 2012; Blonigen and Piger, 2011; Eicher, Helfman, and Lenkoski, 2012; Kirfa-Schneider and Matei, 2010; Mathur and Kartikeya, 2013; Mohamed and Sidiropoulos, 2010; Onyeiwu and Shrestha, 2004).

Until recently, however, the role of host country institutions in attracting FDI received limited attention. That began to change in the 1990s, as researchers began gathering cross-national data on governance and formulating a methodology for ranking countries on the basis of expert perceptions of the quality of their governing institutions. Empirical evidence that factors such as levels of corruption, the transparency of justice systems, and the extent to which property rights are protected and contracts enforced were closely linked to FDI flows to developing countries led to a change in scholarly perceptions on the relationship between FDI and formal institutions (UNCTAD, 2003).

Brunetti and Weder (1999) found that weak respect for the rule of law and high levels of corruption negatively affected private investment in the 60 countries they studied and had the highest statistical significance of all of the 24 economic and political uncertainty variables.

Globerman and Shapiro (2003) found that countries with more impartial and transparent legal systems and better protection of property rights tend to attract more US FDI. An appropriate institutional infrastructure helps foreign investors to engage in value-adding activities that advance the dynamic comparative advantage of host countries (Dunning, 1996, 1998; Porter, 1994, 1996, 1998). A study of a sample of 125 countries from different geographical areas shows that the quality of formal institutions is as strong a determinant of FDI as other variables such as market size, trade orientation, or economic growth. Also, differences in the quality of formal institutions between home and host countries (institutional distance) have a negative effect on FDI (Belay Seyoum, 2009).

Recent studies have examined the impact of a single governance variable (rather than multiple variables or a composite) on FDI flows, for instance, corruption and its effect on FDI (Habib \& Zurawicki, 2002; Park, 2003; Zhao, Kim \& Du, 2003). Some literature supports the claim that the degree of country risk faced by multinational corporations is correlated with international variation in private investment (Barro, 1996; Sala-i-Martin, 1997).

Evidence also suggests that political instability can lead firms to avoid (Delios and Henisz, 2003), minimize (Delios and Henisz, 2000; Uhlenbruck et al., 2006) their investment levels, investments in a country's infrastructures (Bergara et al., 1998; Levy \& Spiller, 1994) or to increase the mortality rates of companies (Carroll and Delacroix, 1982).

In conclusion, findings of recent studies show that the quality of the host country's governing institutions is a major determinant of FDI flows to developing nations. Countries with strong formal institutions (i.e., independent judiciary, effective legal systems, secure property rights etc.), tend to receive more FDI than others, ceteris paribus.

Thus, research suggests the existence of a positive correlation between the quality of governing institutions within nations and their attractiveness to outside investors. The next step is to empirically test this expectation in the African context, where abundant natural resources may trump the demand for transparent governing institutions. 


\section{FDI in Africa}

Africa has been attracting an increasing amount of inward FDI over the past two decades, with inflows rising from $\$ 2.4$ billion in 1985 to $\$ 88$ billion in 2008 (UNCTAD, 2008). This increase has been due to the twin forces of increased commodity prices and a more positive environment for investment. Though less restrictive compliance criteria and less cumbersome approval procedures have contributed to shoring up the level of FDI, political instability still poses a major problem.

The region's largest natural resource producers - such as Angola, Algeria, Nigeria and South Africa -- account for more than three quarters of the FDI inflows to the continent. With countries like the United States reducing their dependence on Middle East, the demand is particularly high for oil (UNCTAD, 2008). For the year 2009, the ranking of the top 5 countries in the order of FDI was South Africa, Egypt, Morocco, Mauritius and Nigeria (Hegarty, 2009). The regional distribution of the total FDI inflows in 2009 was: North Africa (27.6 percent), West Africa (29.9 percent), Central Africa (4.6 percent), East Africa (6.9 percent) and Southern Africa (31.0 percent) (UNCTAD, 2010).

At the end of 2006, Africa was host to about 6400 foreign affiliates of transnational corporations (TNCs). Most of the FDI stock in Africa originates in a few European Union countries - namely the UK, France, Portugal and Italy and North America, mainly the United States. Leading developed country sources of FDI in some top host countries include: (a) UK in South Africa, Madagascar and Mauritius (b) France in Morocco (c) United States in Egypt and (d) Italy in Tunisia. The favored industries for investment include tourism, food and beverages, brewing, textiles and leather, telecommunications, agriculture, mining and quarrying (UNCTAD, 2008).

In order to maximize FDI flows, African countries have implemented changes to their national laws governing FDI. These include reduction in the limitations on foreign ownership of companies and investment incentives. They have also signed several Bilateral Investment Treaties (BITs) to protect investors against political risks in the host country. Besides BITs, countries have signed DTTs (Double Tax Treaties), though the concentration of those is lower. African countries are members in multilateral instruments and related organizations like the Investment Center for Settlement of Investment Disputes (ICSID), Multilateral Investment Guarantee Agency (MIGA) and World Trade Organization (WTO) (UNCTAD, 2008).

African countries are becoming increasingly dependent on FDI as a source of development finance. Due to herd mentality among decision-makers of multinational corporations, there is a self-reinforcing effect of FDI, i.e., knowledge about investment opportunities in host countries plays an important role in increasing its inflow. If we take into account the combined forces of all the countries in the continent, Africa would be the $10^{\text {th }}$ largest economy in the world. However, the market is not monolithic and can broadly be classified into 3 categories, on the basis of income. To tap into the market, companies need to understand the market more closely and get involved with local institutions. Despite the slowdown of the global economy in 2008, TNCs interest in Africa has remained high, particularly in primary sectors. However, a comparison of UNCTAD's index of inward FDI performance to that of inward FDI potential shows that the inflows are still far below potential. Majority of the investing companies have increased investment in the region from 2007 to 2009 and the expected investment remains strong (UNCTAD, 2008).

\section{Data, Variables, and Methodology}

To test our expectations, we gathered yearly data on 53 African nations over a recent 11-year period (1996-2006) from the World Bank's Database of Political Institutions. Our dependent variable is FDI net inflows, measured as a percentage of GDP in millions of current U.S. dollars. To examine the dependency of FDI performance on a nation's political climate, we rely on six variables obtained from the World Bank's Worldwide Governance Indicators project. The variables, which are listed below, were constructed with reference to several surveys of both experts and regular citizens within each nation:

- Voice and Accountability: gauges the extent to which citizens have a say in government, freedom of expression, freedom of association, and freedom of the media.

- Political Stability: measures perceptions that the government will be overthrown by violent means.

- Government Effectiveness: measures the quality of public services and the insulation of the civil service from political pressures.

- Regulatory Quality: captures the government's ability to generate policies and regulations that promote development in the private sector.

- Rule of Law: measures how well actors in a nation abide by the code of the law. This includes the quality of contract enforcement, the police, the courts, and the likelihood of crime and violence. 
- Control of Corruption: measures the extent to which public goods are exploited by private individuals.

The bivariate correlations among these variables are high, ranging from .635 to .895 . These high correlations may be due to true, empirical relationships among the variables, but may also arise from their shared dependence on a common underlying dimension. To test whether each of these variables are actually manifestations of their dependence on a shared latent variable, we conduct a principal components analysis. The analysis reveals that a single component accounts for $79 \%$ of the total variance in these variables, evidence for this assertion. As such, we create a new variable, named institutional quality, which is simply the score of each nation, in any given year, on this underlying component. The variable has a mean of 0 , a standard deviation of 2.18 , and covers 463 country-year dyads for which information on each of the six constituent variables was available.

To display the distribution of nations on this new variable, we first take the mean of each nation's value on the index over the years for which we have data (generally 1996-2006, though there is missing data for some nations). Figure 1 displays this institutional quality score with a dot plot. Mauritius and Botswana have the highest scores on this index, while Somalia and the Democratic Republic of the Congo score lowest.

In Figure 2 we display the mean value of FDI, as a percentage of GDP, across each year that data was available. Four countries, Libya, Namibia, Somalia, and Zimbabwe, are excluded from the chart as there is no data on FDI for these nations. The chart shows that Liberia and Equatorial Guinea have the highest net FDI inflows (as a percentage of GDP), while Gabon and Burundi have the lowest.

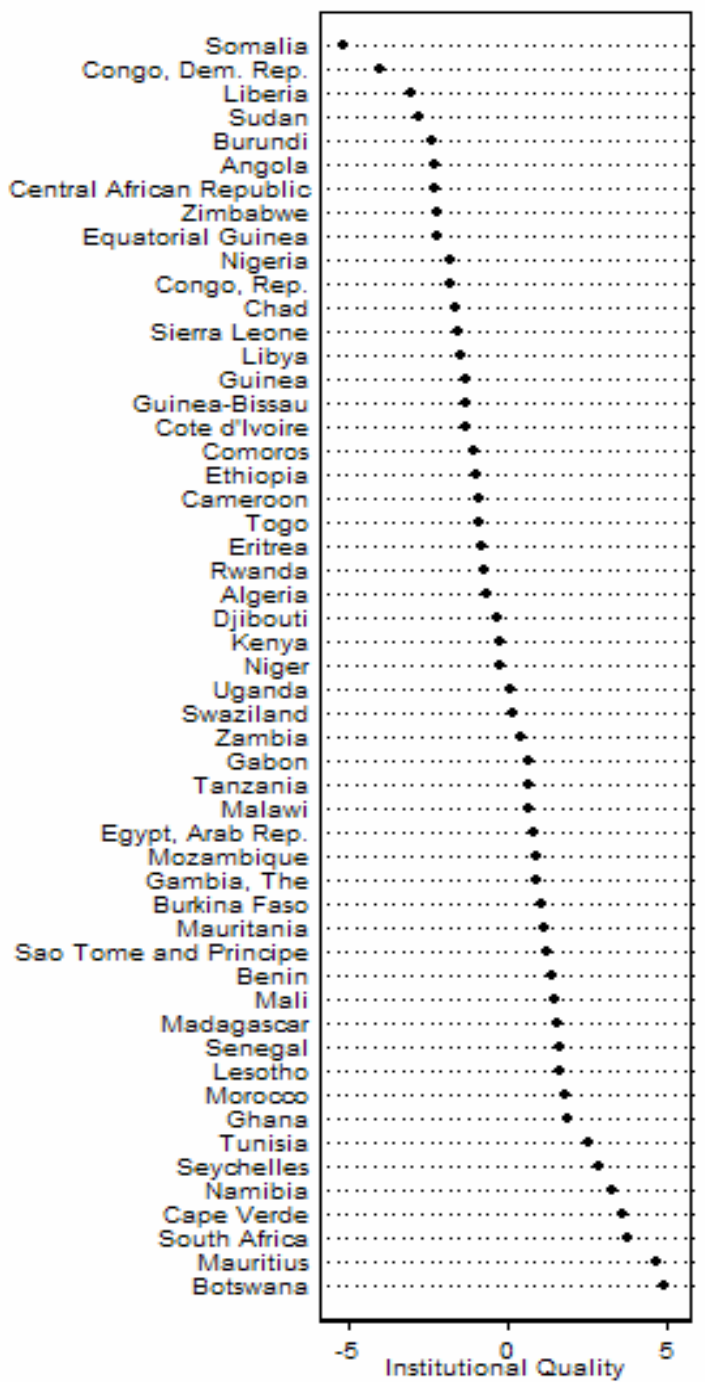

Figure 1. Institutional quality across African nations 


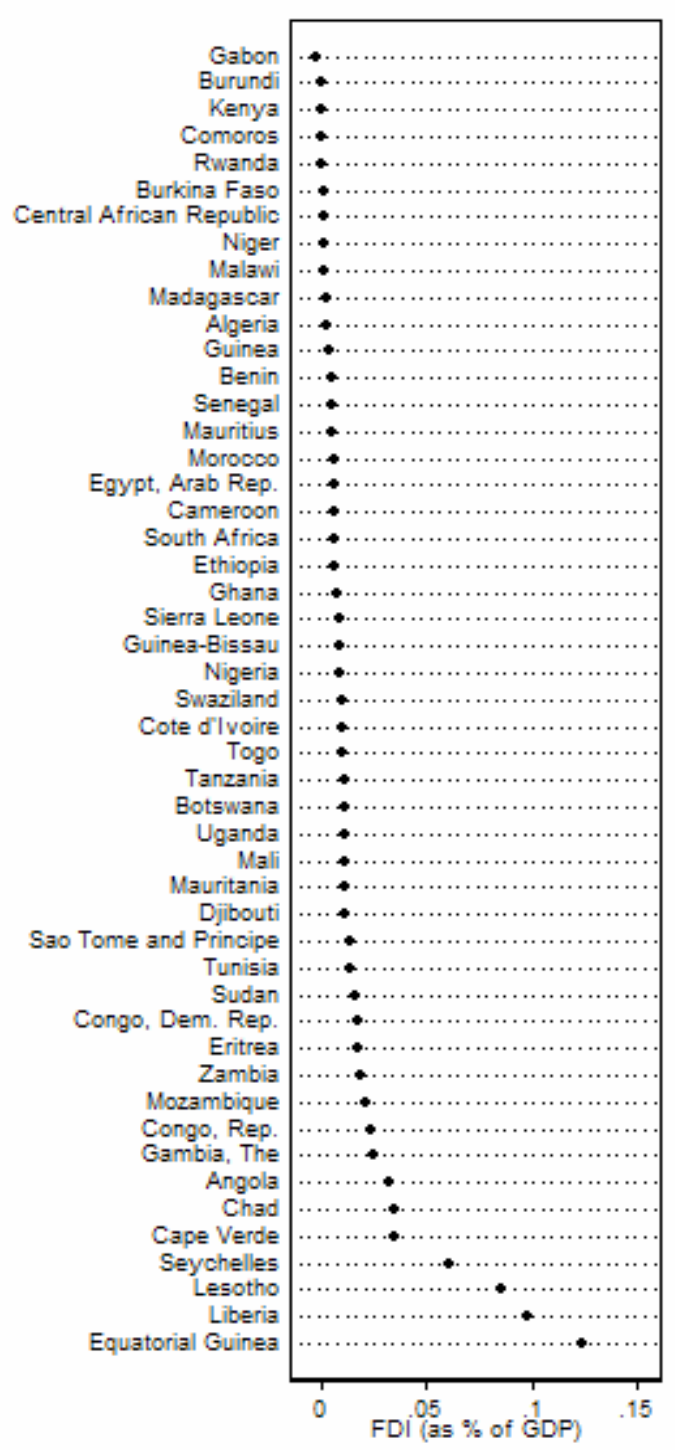

Figure 2. Foreign Direct Investment across African nations

As noted above, previous theory indicates that as the political institutions of a nation strengthen, they become more attractive to outside investment. However, when a nation is rich in natural resources, the importance of institutional quality should decline. To test this theory, we gathered data on the natural resource climate in each African nation. More specifically, we create two dummy variables, oil and natural gas. The oil variable equals one for nations with oil reserves, and zero otherwise. Similarly, the natural gas variable equals one for nations with natural gas reserves, and zero otherwise.

We employ dummy variables because the use of true time series data on natural resource reserves poses a serious endogeneity problem; a country's reserves may be depleted due to active foreign business involvement (hence, high FDI), which introduces endogeneity into the equation. That is, an increase in FDI, our dependent variable, will lead to a decrease in natural resource reserves, our independent variable. In the case of endogeneity, single-equation regression techniques will return biased and inconsistent parameter estimates. Thus, we opt to use dummy variables to capture the presence of natural resources. Though such an approach means we miss some of the variation in natural resource reserves within and across countries, it lessens the likelihood that our econometric tests will be plagued with endogeneity problems.

We also control for GDP growth in the previous year, under the assumption that investors are more likely to enter a flourishing economic climate. We obtain information on this variable from the World Bank's World Development 
Indicators data set. Our dependent variable in this analysis is again FDI in millions of current US dollars as a percentage of GDP, and our key independent variable is the composite institutional quality measure. Each variable is summarized in Table 1.

Table 1. Summary statistics

\begin{tabular}{lccc}
\hline & $n$ & mean & standard deviation \\
\hline FDI (as \% of GDP) & 581 & 0.017 & 0.045 \\
Institutional Quality & 463 & 0.000 & 2.183 \\
Oil & 689 & 0.283 & 0.451 \\
Natural Gas & 689 & 0.434 & 0.496 \\
Lagged GDP Growth & 606 & 4.739 & 7.946 \\
\hline
\end{tabular}

The nature of our hypothesis is conditional. That is, we expect institutional quality to positively affect FDI only when natural resources are not present. To test this expectation, we create an interactive model, depicted formally in Equation 1:

$$
\begin{gathered}
\mathrm{FDI}_{i, t}=\beta_{0}+\beta_{1} \text { institutional quality }_{i, t}+\beta_{2} \text { natural } \text { resources }_{i, t}+\beta_{3} \text { (natural resources }_{i, t} \times \text { institutional quality) } \\
+\beta_{4} \text { lagged GDP } \text { growth }_{i, t}+\varepsilon_{i, t},
\end{gathered}
$$

where $i$ indexes countries, $t$ indexes time periods, $\beta_{0}$ is a constant term and $\varepsilon$ captures random error. The natural resources variable in the equation is either the oil dummy or the natural gas dummy, meaning we will actually estimate two equations. We expect that $\beta_{1}$ will be positive, indicating a positive relationship between institutional quality and FDI, and $\beta_{3}$ will be negative, meaning that this relationship will be attenuated in the presence of natural resources.

Though this is a linear model, because of the time-series cross-sectional nature of our data, ordinary least squares (OLS) regression is inefficient in that its associated standard errors will be incorrect. This is because each country in our model may have unique error variance (panel heteroscedasticity) and the error in one country may be correlated with the error in another during the same year (contemporaneous error correlation), violating the Gauss-Markov assumptions used to justify OLS (Beck 2001). The standard approach to overcome these problems is to use OLS with panel corrected standard errors (PCSEs) (Beck and Katz, 1995), which correctly measure the sampling variance of the OLS estimates of the $\beta_{\mathrm{k}}$ 's in Equation 1.

In addition, the errors in one nation may also be correlated with previous errors in that same nation (serial error correlation). Standard practice now models dynamics with a lagged dependent variable (LDV) (Beck, 2001). To test for the presence of serial correlation in our model, we use a Wooldridge (2002) test for serial correlation in panel data. The $p$-value for the null hypothesis of no serial correlation is 0.00 in both the equation with the oil dummy and the equation with the natural gas dummy, indicating that the errors in our model are likely temporally interdependent. Thus, we opt to use both PCSEs and LDVs to capture serial correlation.

\section{Results}

Due to missing data, we are left with 371 observations on 48 countries. (Note 1) There is an average of 7.73 observations per country, a minimum of 7 , and a maximum of 8 . Table 2 summarizes the results of each estimation.

The results corroborate our theoretical expectations. The coefficient on institutional quality in each model captures the effect of the variable when natural resources are not present. In both models the coefficient is positive and significant, meaning that positive changes in the quality of political institutions are associated with increased FDI in nations without oil or natural gas. Conversely, in nations that are rich in these resources, the positive effect of institutional quality on FDI is not present. In fact, there is a weakly negative association between institutional quality and FDI in such countries. This can be seen by adding the coefficient on the interaction term to the coefficient on institutional quality in each equation. (Note that the one-sided $p$-value on the conditional slope of institutional quality is .109 in countries without oil and .028 in countries without natural gas.)

To better display the conditional effect of institutional quality, we plot its conditional slopes in Figures 3 and 4. Again, the slope of institutional quality is positive when natural resources are not present. Alternatively, when oil or 
natural gas is present, this slope attenuates and becomes slightly negative. Clearly, the quality of political institutions only boosts investment from multinational firms when countries lack oil and natural gas. Alternatively, when countries are rich in one of these resources, the quality of political institutions plays less of a role in the investment decisions of such firms.

Table 2. The conditional effect of institutional quality on FDI

\begin{tabular}{|c|c|c|c|c|}
\hline & \multicolumn{2}{|c|}{ Model 1} & \multicolumn{2}{|c|}{ Model 2} \\
\hline & Coef. & $p$-value & Coef. & $p$-value \\
\hline Lagged FDI (as \% of GDP) & 0.538 & .004 & 0.541 & .004 \\
\hline Institutional Quality & 0.003 & .048 & 0.003 & .044 \\
\hline Oil & 0.005 & .011 & & \\
\hline Institutional Quality $\times$ Oil & -0.004 & .018 & & \\
\hline Natural Gas & & & 0.003 & .147 \\
\hline Institutional Quality $\times$ Nat. Gas & & & -0.005 & .013 \\
\hline Lagged GDP Growth & 0.001 & .210 & 0.001 & .215 \\
\hline constant & 0.001 & .345 & 0.002 & .274 \\
\hline Number of Countries & \multicolumn{2}{|c|}{48} & \multicolumn{2}{|c|}{48} \\
\hline Number of Time Periods & \multicolumn{2}{|c|}{371} & \multicolumn{2}{|c|}{371} \\
\hline $\mathrm{R}^{2}$ & \multicolumn{2}{|c|}{0.274} & \multicolumn{2}{|c|}{0.273} \\
\hline Prob $>$ chi $^{2}$ & \multicolumn{2}{|c|}{0.000} & \multicolumn{2}{|c|}{0.000} \\
\hline
\end{tabular}

Note: One-sided $p$-values based on panel-corrected standard errors.

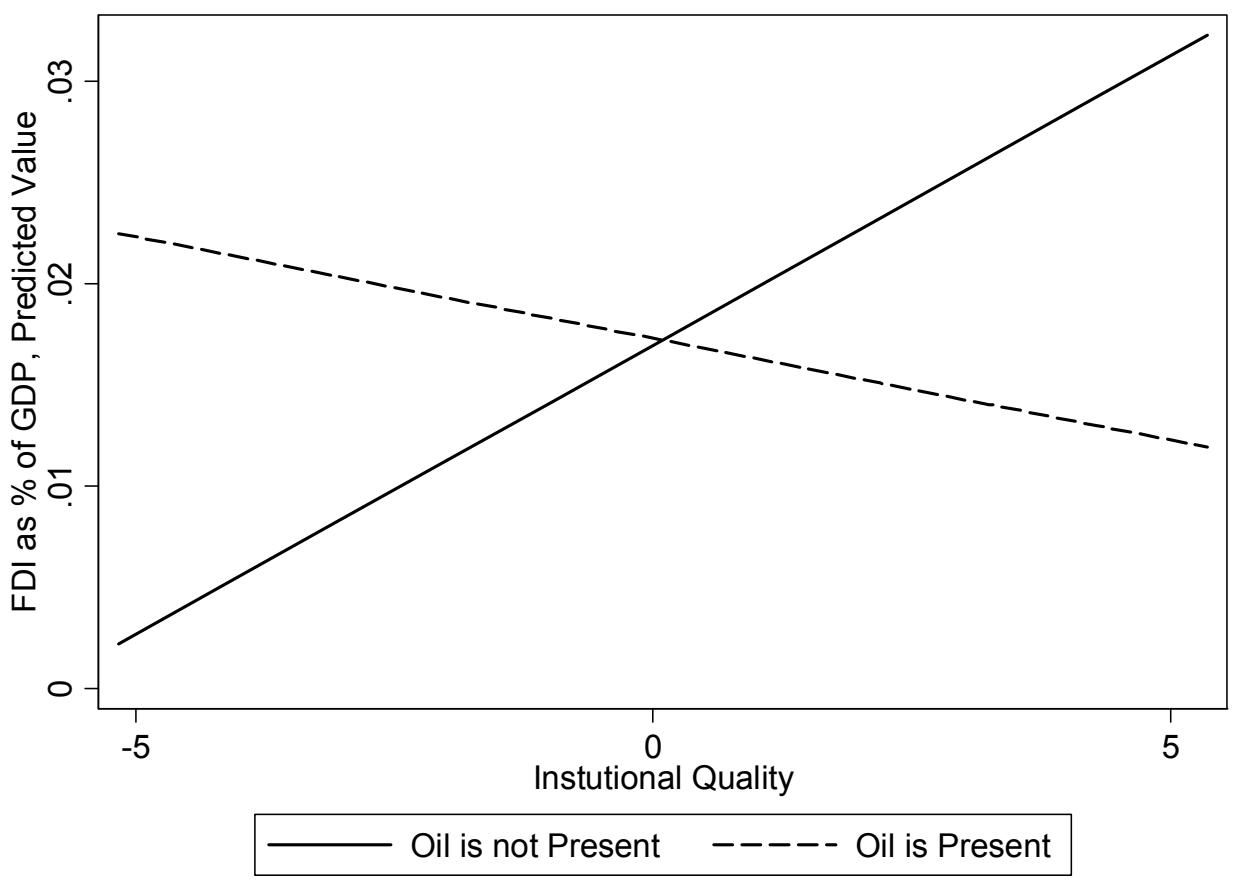

Figure 3. The conditional effect of institutional quality - oil 


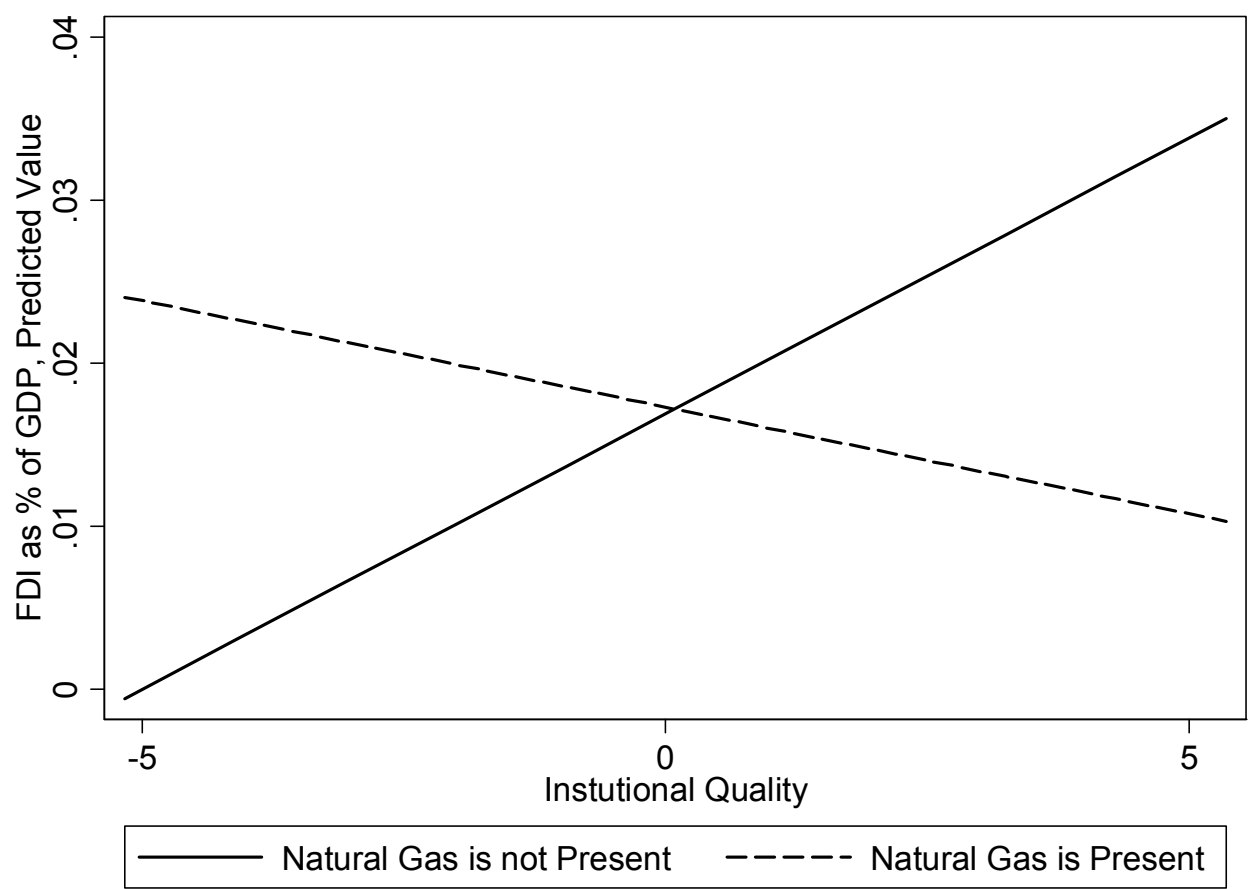

Figure 4. The conditional effect of institutional quality - natural gas

\section{Implications and Future Research}

It is clear from the research findings that the quality of political institutions has a direct impact on foreign direct investment flows in nations without oil or gas. The implications are twofold. First, countries that lack (or do not possess in abundance) natural resources will be pressed to ensure that their formal institutions are strong and competitive. This includes administrative and legal structures, property rights regimens and tax systems. A welcoming, transparent, and pro-market business environment will be a necessity rather than a choice, since these natural resource-poor countries will be competing not only with oil and gas producing nations but with economically similar countries like themselves. Gambia, Zambia, and Sierra Leone are examples.

Second, the study results imply that oil and gas producing African countries such as Nigeria, Angola, and Algeria need not undertake measures to improve the quality of their institutions, since the continuous demand in global markets for their natural resources will attract multinational firms regardless of the governance conditions in their nations. However, complacency could prove short-sighted and an unwise state of being for oil and gas-producing nations. First, wide fluctuations in demand and production (especially by non-OPEC nations) as well as alternative energy development not to mention advanced technologies in the production of fossil fuels imply falling prices (and low-price stabilization) in the future. Second, oil producing nations that proactively improve their institutions (and in the case of South Africa possess a large internal market) will enjoy the best of both worlds - attracting substantial foreign investment in both the natural resource and non-resource sectors.

Future research may wish to: (1) compare Africa to other emerging markets to discern similarities and differences in the amount, nature and sequencing of FDI flows; (2) discern governing institution impact on various sectors such as software, consumer products, agriculture, and financial services; and investigate if, how, and to what extent human capital and workforce factors and their corresponding institutions (schools, unions) impact FDI behavior.

\section{References}

Abbott, Andrew, Cushman, D.O., \& De Vita, Glauco. (2012). Exchange Rate Regimes and Foreign Direct Investment Flows to Developing Countries. Review of International Economics, 20(1), 95-107. http://dx.doi.org/10.1111/j.1467-9396.2011.01010.x

Acemoğlu, D., \& Johnson, S. (2005). Unbundling institutions. Journal of Political Economy, 113(5), 949-995. http://dx.doi.org/10.1086/432166 
Al-Sadig, Ali J. (2013). Outward Foreign Direct Investment and Domestic Investment: The Case of Developing Countries. IMF Working Paper (WP 13/52).

Anghel, B. (2005). Do Institutions Affect Foreign Direct Investment? Master's Thesis. Universidad de Barcelona. Barcelona, Spain.

Barro, D. (1996). Democracy and growth. Journal of Economic Growth, 1, 1-27. http://dx.doi.org/10.1007/BF00163340

Beck, Nathaniel, \& Katz, Jonathan N. (1995). What to do (and not to do) with time-series cross-section data. American Political Science Review, 89(3), 634-647. http://dx.doi.org/10.2307/2082979

Beck, Nathaniel. (2001). Time-series cross-section data: what have we learned in the past few years?. Annual Review of Political Science, 4, 271-293. http://dx.doi.org/10.1146/annurev.polisci.4.1.271

Bergara, M.E., Henisz, W.J., \& Spiller, P.T. (1998). Political institutions and electric utility investment: A cross-national analysis. California Management Review, 40(2), 18-35. http://dx.doi.org/10.2307/41165931

Blomstrom, M., \& Kokko, A. (2001). Foreign direct investment and spillovers of technology. International Journal of Technology Management, 22(5-6), 435-454.

Blonigen, B., \& Piger, J. (2011). Determinants of foreign direct investment. National Bureau of Economic Research Working Paper 16704.

Brunetti, A., \& Weder, B. (1997). Investment and Institutional Uncertainty: A Comparative Study of Different Uncertainty Measures. Technical Paper Number 4, Washington, D.C.: World Bank. http://dx.doi.org/10.1596/0-8213-4159-6

Buckley, P.J., \& Casson, M.C. (1976). The Future of the Multinational Enterprise. London: Macmillan.

Busse, M., \& Groizard, J.L. (2006). FDI, regulations and growth. HWWA Discussion Paper 342, Hamburg Institute of International Economics.

Busse, M., \& Hefeker, C. (2005). Political risk, institutions and foreign direct investment. HWWA Discussion Paper 315, Hamburg Institute of International Economics.

Carroll, G.R., \& Delacroix, J. (1982). Organizational mortality in the newspaper industries of Argentina and Ireland: An ecological approach. Administrative Science Quarterly, 27, 169-198. http://dx.doi.org/10.2307/2392299

de Soto, H. (1989). The Other Path Economic Answer to Terrorism. New York: Perseus Books.

de Soto, H. (2000). The Mystery of Capital: Why Capitalism Triumphs in the West and Fails Everywhere Else. New York: Basic Books.

De Vita, G., \& Kyaw, K. (2008). Determinants of FDI and portfolio flows to developing countries: a panel cointegration analysis. European Journal of Economics, Finance and Administrative Sciences, 13, 161-168.

Delios, A., \& Henisz, W.J. (2000). Japanese firms' investment strategies in emerging economies. Academy of Management Journal, 43(3), 305-323. http://dx.doi.org/10.2307/1556397

Delios, A., \& Henisz, W.J. (2003). Political hazards and the sequence of entry by Japanese firms. Journal of International Business Studies, 34(3), 227-241.

Dunning, J.H. (1977). Trade, location of economic activity and the MNE: A search for an eclectic approach. In Ohlin, B., Hesselborn, P. and Wijkman, J. (Eds.), The International Allocation of Economic Activity. New York: Holmes and Meier.

Dunning, J.H. (1996). The geographical sources of competitiveness of firms: the results of a new survey. Transnational Corporations, 5(3), 1-30.

Dunning, J.H. (1998). Location and the multi-national enterprise: A neglected factor. Journal of International Business Studies, 29(1), 45-66. http://dx.doi.org/10.1057/palgrave.jibs.8490024

Eicher, T., Helfman, L., \& Lenkoski, A. (2012). Robust FDI determinants: Bayesian model averaging in the presence of selection bias. Journal of Macroeconomics, 34(3), 637-651. http://dx.doi.org/10.1016/j.jmacro.2012.01.010

Fan, J.P.H., Morck, R., Xu, L.C., \& Yeung, B. (2007). Does 'good governance' draw foreign capital? explaining China's exceptional foreign direct investment inflow. World Bank Policy Research Working Paper 4206. Washington, D.C.: World Bank. 
French, H.W., \& Polgreen, L. (2007). China, filling a void, drills for riches in Chad. The New York Times, August 13.

Garnett, J. (1992). Communicating for results in government: a strategic approach for public managers. Public Productivity and Management Review, 16(2), 219-222. http://dx.doi.org/10.2307/3380994

Glaeser, E. L., La Porta, R., López de Silanes, F., \& Shleifer, A. (2004). Do institutions cause growth?. Journal of Economic Growth, 9(3), 271-303. http://dx.doi.org/10.1023/B:JOEG.0000038933.16398.ed

Globerman, S., \& Shapiro, D. (2002). Global Foreign Direct Investment Flows: the Role of Governance Infrastructure. World Development, 30(1), 1899-1919. http://dx.doi.org/10.1016/S0305-750X(02)00110-9

Globerman, S., \& Shapiro, D. (2003). Governance infrastructure and U.S. foreign direct investment. Journal of International Business Studies, 34(1), 19-39. http://dx.doi.org/10.1057/palgrave.jibs.8400001

Grubaugh, Stephen G. (2013). Determinants of Inward Foreign Direct Investment: A Dynamic Panel Study. International Journal of Economics and Finance, 5(12), 104-109. http://dx.doi.org/10.5539/ijef.v5n12p104

Habib, M., \& Zurawickim, L. (2002). Corruption and foreign direct investment. Journal of International Business Studies, 33(2), 291-318. http://dx.doi.org/10.1057/palgrave.jibs.8491017

Hall, R.E., \& Jones, C.I. (1999). Why do some countries produce so much more output per worker than others?. The Quarterly Journal of Economics, 144(1), 83-116. http://dx.doi.org/10.1162/003355399555954

Harms, P., \& Ursprung, W. (2002). Do civil and political repression really boost foreign direct investments?. Economic Inquiry, 40(4), 651-663. http://dx.doi.org/10.1093/ei/40.4.651

Hegarty, J. (2009). Awards: African Countries of the Future 2009/10. Foreign Direct Investment Magazine.

Hussain, F., \& Kimuli, C.K. (2012). Determinants of Foreign Direct Investment Flows to Developing Countries. SBP Research Bulletin, 8(1), 1-31.

Hymer, S. (1976). The International Operations of National Firms: A Study of Direct Foreign Investment. Cambridge, MA: MIT Press.

Jensen, N. (2003). Democratic governance and multinational corporations: the political economy of foreign direct investment. International Organization, 57(3), 587-616. http://dx.doi.org/10.1017/S0020818303573040

Kaufman, D., Kraay, A., \& Mastruzzi, M. (2005). Governance Matters IV: Governance Indicators 1996-2004. Washington, D.C.: World Bank. http://dx.doi.org/10.1596/1813-9450-3630

Kaufman, D., Kraay, A., \& Zoido-Lobatón, P. (1999a). Aggregating Governance Indicators. Washington, D.C.: World Bank.

Kaufman, D., Kraay, A., \& Zoido-Lobatón, P. (1999b). Governance Matters. Washington, D.C.: World Bank.

Kearsey, A., \&Varey, R. (1998). Managerialist thinking on marketing for public services. Public Money and Management, 18(2), 51-60. http://dx.doi.org/10.1111/1467-9302.00116

Keele, Luke, \& Kelly, Nathan. (2006). Dynamic models for dynamic theories: the ins and outs of lagged dependent variables. Political Analysis, 14, 186-205. http://dx.doi.org/10.1093/pan/mpj006

Kirfa-Schneider, H., \& Matei, I. (2010). Business climate, political risk and FDI in developing countries: Evidence from panel data. International Journal of Economics and Finance, 2(5), 54-65.

Knack, S., \& Keefer, P. (1995). Institutions and economic performance: cross-country tests using alternative $\begin{array}{lllll}\text { institutional measures. } & \text { Economics }\end{array}$ http://dx.doi.org/10.1111/j.1468-0343.1995.tb00111.x

Kobrin, S. (1979). Political risk: a review and reconsideration. Journal of International Business Studies, 10(1), 67-80. http://dx.doi.org/10.1057/palgrave.jibs.8490631

Kuo, Hsien-Chang, \& Li, Yang. (2003). A dynamic decision model of SMEs. Small Business Economics, 20(3), 219-231. http://dx.doi.org/10.1023/A:1022819206036

Levy, B., \& Spiller, P.T. (1994). The institutional foundations of regulatory commitment: A comparative analysis of telecommunications regulation. Journal of Law, Economics, and Organization, 10, 201-246. 
Li, Q., \& Resnick, A. (2003). Reversal of fortunes: democratic institutions and foreign direct investment inflows to $\begin{array}{lllll}\text { developing } & \text { countries. } & \text { International }\end{array}$ http://dx.doi.org/10.1017/S0020818303571077

$\mathrm{Li}$, S. (2005). Why a poor governance environment does not deter foreign direct investment: the case of China and its implications for investment protection. Business Horizons, 48(4), 297-302. http://dx.doi.org/10.1016/j.bushor.2004.06.002

Lskavyan, V., \& Spatareanu, M. (2007). Host country's governance and the size of foreign investors. Rutgers University Working Paper \#2007-004.

Maskus, K.E. (1998). The role of intellectual property rights in encouraging foreign direct investment and technology. Duke Journal of Comparative and Intellectual Law, 9(1),109-161.

Mathur A., \& Kartikeya, S. (2013). Foreign direct investment, corruption and democracy. Applied Economics, 45(8), 991-1002. http://dx.doi.org/10.1080/00036846.2011.613786

Mauro, P. (1995). Corruption and growth. The Quarterly Journal of Economics, 110(3), 681-712. http://dx.doi.org/10.2307/2946696

Meyer, K.E., \& Nguyen, H.V. (2005). Foreign investment strategies and sub-national institutions in emerging markets: evidence from Vietnam. Journal of Management Studies, 42(1), 63-93. http://dx.doi.org/10.1111/j.1467-6486.2005.00489.x

Mohamed, S., \& Sidiropoulos, M. (2010). Another look at the determinants of foreign direct investment in MENA countries: An empirical investigation. Journal of Economic Development, 35(2), 75-95.

North, D. (1981). Structure and Change in Economic History. New York: Norton.

North, D. (1990). Institutions, Institutional Change and Economic Performance. Cambridge, U.K.: Cambridge University Press.

Onyeiwu, S., \& Shrestha, H. (2004). Determinants of Foreign Direct Investment in Africa. Journal of Developing Societies, 20(1-2), 89-106.

Park, H. (2003). Determinants of corruption: A cross-national analysis. Multinational Business Review, 11(2), 29-45. http://dx.doi.org/10.1108/1525383X200300010

Porter, M.E. (1994). The role of location in competition. Journal of Economics of Business, 1(1), 35-39. http://dx.doi.org/10.1080/758540496

Porter, M.E. (1996). Competitive advantage, agglomerative economics and regional policy. International Regional Science Review, 19, 85-94.

Porter, M.E. (1998). The Adam Smith address: Location, clusters and the "new" microeconomics of competition. Business Economics, 33(1), 7-13.

Rauch, J., \& Evans, P. (2000). Bureaucratic structure and bureaucratic performance in less developed countries. Journal of Public Economics, 75(1), 49-71. http://dx.doi.org/10.1016/S0047-2727(99)00044-4

Rodrik, D., Subramanian, A., \& Trebbi, F. (2002). Institutions Rule: The Primacy of Institutions over Geography and Integration in Economic Development. Working Paper 9305, National Bureau of Economic Research.

Sala-i-Martin, X. (1997). I just ran a million regressions. Working paper 6252." National Bureau of Economic Research.

Seyoum, B. (1996). The impact of intellectual property rights on foreign direct investment. Columbia Journal of World Business, 31(1), 50-59. http://dx.doi.org/10.1016/S0022-5428(96)90006-X

Seyoum, B. (2009). Formal Institutions and Foreign Direct Investment. Thunderbird International Business Review, 51(2), 165-181. http://dx.doi.org/10.1002/tie.20256

Sichei, M.M., \& Kinyondo, G. (2012). Determinants of Foreign Direct Investment in Africa: A Panel Data Analysis. Global Journal of Management and Business Research, 12(18), 85-97.

Soumia, Z., \& Abderrezzak, B. (2013). The Determinants of Foreign Direct Investment and Their Impact on Growth: Panel Data Analysis for AMU Countries. International Journal of Innovation and Applied Studies, 2(3), 300-313. 
Stasavage, D. (2002). Private investment and political institutions. Economics and Politics, 14(1), 41-63. http://dx.doi.org/10.1111/1468-0343.00099

Stein, E., \& Daude, C. (2001). Institutions, integration and the location of foreign investment. Inter-American Development Bank, Research Department, Washington: D.C.

Uhlenbruck, K., P. Rodriguez, J. Doh, \& L. Eden. (2006). The impact of corruption on entry strategy: Evidence from telecommunication projects in emerging economies. Organization Science, 17(3), 402-414 http://dx.doi.org/10.1287/orsc.1060.0186

UNCTAD. (2003). World Investment Report: FDI Policies for Development: National and International Perspectives. New York: United Nations Conference on Trade and Development.

UNCTAD. (2008). World Investment Report: Transnational Corporations and the Infrastructure Challenge. New York: United Nations Conference on Trade and Development.

UNCTAD. (2010). FDI in Africa. Policy Brief No.4.

Vernon, R. (1971). Sovereignty at Bay. New York: Basic Books.

Wei, S.J. (2000). How taxing is corruption on international investors?. The Review of Economics and Statistics, 82(4), 1-12. http://dx.doi.org/10.1162/003465300558533

Wells, L.T., \& Gleason, E.S. (1995). Is foreign infrastructure investment still risky. Harvard Business Review, 73(5), 44-53.

Wernick, D., Haar, J., \& Singh S. (2009). Do Governing Institutions Affect Foreign Direct Investment? New Evidence from Emerging Economies. International Journal of Economics and Business Research, 1(3), 317-332. http://dx.doi.org/10.1504/IJEBR.2009.024307

Wheeler, D., \& Mody, A. (1992). International investment location decisions: The case of U.S. firms. Journal of International Economics, 33(1-2), 57-76.

Wooldridge, Jeffrey M. (2002). Econometric Analysis of Cross Section and Panel Data. Cambridge, MA: MIT Press.

World Bank. (2005). Economic Growth in the 1990s: Learning from a Decade of Reform. Washington, D.C.: World Bank. http://dx.doi.org/10.1596/0-8213-6043-4

Zhao, H., S. Kim, \& Du, J. (2003). The impact of corruption and transparency on foreign direct investment: An empirical analysis. Management International Review, 43(1), 41-62.

\section{Note}

Note 1. Missing data prevents the inclusion of Libya, Namibia, São Tomé and Principe, Somalia, and Zimbabwe in the equations. 